\title{
Obituary: John V. Leigh, OBE, BSc, FICE, FIAT, FIHT
} 1916-2009

Born in 1916, John Leigh was educated at Christ's Hospital and Imperial College where he graduated in civil engineering in 1937. He served in the Royal Engineers between 1939 and 1946 initially as an intelligence officer. He left for Normandy on D-day +1 where he commanded a company in the newly formed Airfield Construction Group. As part of the Canadian Army they went round the coastal flank building forward airfields and repairing existing ones which he described as an interesting experience! He was awarded the MBE and mentioned in despatches.

He considered himself to be very fortunate to be appointed as a bridge engineer under James Drake in Lancashire. It was here that he really started his long association with motorway construction and also helped to produce the Road Plan for Lancashire, one of the earliest documents of its kind in the country.

In 1953 he gained promotion to assistant county surveyor of Staffordshire where he was in charge of major construction. With Fred Jepson, the county surveyor, he walked the whole length of the line of the proposed M6 in the county in 1957. He moved on to be deputy county surveyor in Berkshire and in 1962 was appointed county surveyor of Hertfordshire.

During his time in Hertfordshire the Road Construction Units were set up to design and build motorways and he was chief engineer of the Hertfordshire Sub Unit. During the next 9 years the M1 was extended south to the North Circular and the A1(M) was on its way to completion. The lines of the M25 and M11 as they touched Hertfordshire were fixed. The budget was around $£ 10$ million (almost $£ 100$ million at today's prices). Other changes were that Middlesex was taken into Greater London and three new towns were completed. He had an excellent staff and was proud to be at their head. Anyone who worked for him will testify that the view was reciprocated. It was an important county lying along the north side of London and as he said "there was much to do and by and large we did it'.

In 1971 he was invited to accept an appointment as director general of a trade association, the Asphalt and Coated Macadam Association, based in London. Using his background and his skilled team, further standards for 'black top' were developed. He was appointed an OBE in 1977.

He initially qualified in the Institution of Civil Engineers in 1939, later joining the Institution of Municipal Engineers and winning their Richard Pickering prize in the early 1950s for a paper on traffic engineering, an early venture in this field. He was more active in the Institution of Highway Engineers (now the Institution of Highways and Transportation) of which he was president in 1973-1974 when his packed presidential conference held at Church House Westminster was on the topic of 'standards for modern highways', which was key to the debate then taking place. A keen golfer, he was chairman of their local cup committee which ran the branch's golf competition for 4 years and was subsequently honorary treasurer for 11 years.

John Leigh had promised Edith, his wife, that they would return to the sea on retirement in 1978 and moving to Torquay he became a church warden of St Matthias and one of the drivers of the outstanding church and community centre developed on site. His five replacement hips impeded neither his golf (until later years) nor his spirit, love of travel and joy in life and people.

Born in Brixton March 1916 and died suddenly on 21 April 2009 aged 93. His wife Edith died in 2002 and he is survived by his daughter Frances. 